\title{
Application of Layered Teaching Method in Basketball Teaching in Universities
}

\author{
Jiafang Zhang \\ Zhengzhou Institute of Technology \\ Zhengzhou, China
}

\begin{abstract}
With the attention of society and input in teaching, basketball is getting more and more popular among students. As far as sport itself is concerned, basketball has its own particularity. Sports need a certain support of physical power, when the physical ability can't reach the standard, a universal application in education will certainly cause discomfort of the educated subject. The layered teaching method starting from the actual condition of the student matches the teaching scheme of the student's own condition, and has positive meaning to the improvement of students' basketball skill and teaching quality. The application of layered teaching method considers the reality of the subject accepting basketball education, and it has to confirm according to actual condition in the application of layered teaching method.
\end{abstract}

Keywords-layered teaching method; basketball education; colleges and universities; teaching quality

\section{INTRODUCTION}

As far as the objective of sports development, sports project is to realize the improvement of physical quality of sports subject, realize effect of body building of sports. When classified sport is subdivided to collective activity, the individual that forms the collectivity will not be in a tidy uniform state due to its own condition. On the one hand, such multi-subject condition brings difficulty to teaching, on the other hand, such condition benefits the communication and coordination among sport subjects and plays the role of coordination. In teaching, due to influence of actual teaching condition, the layered teaching method is seldom applied among students, but the importance of layered teaching method in diversified society and the more and more furious competition becomes clearer, and only adopting multiple teaching can really cultivate talents fully develop the talent.

\section{THE CONNOTATION AND PRINCIPLE OF THE LAYERED TEACHING METHOD}

The layered teaching method arises to adapt the change and development of teaching, which does not regard students as a solidified entirety and make students become a same color in teaching, but changes this ideology. The educated students' characteristics are valued by educators, and it does not teach students according to uniform plan, but cultivates students' characteristics and realizes layered diversified education according to students' actual condition. [1] Stick to the teaching method of teaching students in accordance of their aptitude, and teachers pay special attention to the students in education and take different teaching methods and objectives according to students' characteristics, whose ultimate purpose is to develop the potential of students and enable them to achieve certain teaching effect during education.

Firstly, an important feature of the layered teaching method in teaching is layering, which does not regard students as an entirety, but distinguishes little differences through students, and adopts a same or multiple teaching methods in the distinguished similar collection. Of course, in subdivision, the layered education also focuses on every educated individual. There are mainly the following principles in layered education, firstly it is the principle of teaching students in accordance of their aptitude, for the premised assumed condition of layered education is the differentiation of students, namely the student individual is not equal to the condition of collection. The teaching method and concept decides the result of teaching, layered teaching highlights the characteristics of students and teach according to the feature of people. [2] Secondly, it needs to stick to the principle of effectiveness in layered teaching, which refers to the effectiveness of both students' teaching method and their teaching objective. It can only complete the mission of teaching in effective education.

The essence of the research and discussion of layered teaching method is to control the specificity, altering to new teaching mode from traditional teaching concept, and the traditional single teaching objective disperses into several teaching objectives. The teaching objective is decided by the students' actual condition. In layered teaching method, the education grasps the students' features fundamentally, transform the key point of teaching development, indirectly transform the teaching development from quantity to quality. It can be seen no matter from the objective of the teaching method or its principle that the students' subjective color exists, which can be said to adapt the requirement of diversified development of society.[3]

\section{PROBlems EXISTING IN BASKETBALl TEACHING IN UNIVERSITY}

In basketball teaching in university, because basketball belongs to a collective sport, it needs many people to take part in. In professional teaching, teachers generally correct students according to the contrast and difference between 
students' movement and standard movement. It does not get rid of the stale and bring forth the fresh in teaching method, which still teaches normative movement to the students, and the students practice according to the teachers' mission arrangement. In actual teaching, there are many students, besides, the sport is taught outdoors, thus students are easy to get influenced by various factors, and the teaching effect is not obvious. [4] In teaching, students need teachers' guidance, but the teacher resource is limited and they can not execute differentiated education to all the students. It's very common for teachers to pay deficient attention to the individualized development of students, however, in sport education, according to difference of sports projects, there will be different effects of students' division of labor in sports projects according to their own characteristics, and in actual sports teaching, this is not paid attention to.

There is a condition in basketball teaching in universities that students don't learn basketball in teaching but on the field and in live competitions, students find the passion to basketball in live competitions, and accumulate their own basketball knowledge in their competing experience, the function of education is not obvious in teaching, whose reason is that education satisfies only a kind of guidance and does not goes deep into the connotation of teaching or develop the potential value of teaching objective. [5] Of course, this is only for some non-professional sport teaching classes in colleges and universities, and there is formal education mode for professional basketball education, but apparently students' personality is not obvious.

\section{THE MEANING OF APPLICATION OF THE LAYERED TEACHING METHOD IN BASKETBALL TEACHING IN UNIVERSITY}

To analyze the reason for difference in basketball teaching from the current condition of basketball teaching in university, its basis is that the peculiarity of the education receivers are not paid attention to, and the subject of education is homogenized, and in teaching practice, differentiated reality is ignored, but the students have distinct character and it needs a teaching method which conforms to the characters of the students and be led by teaching objective and focus on the person receiving education. The application of layered teaching method in basketball teaching in universities has important meaning.

\section{A. Targeted Teaching Improves Teaching Quality}

The key of layered teaching method is to pay attention to the character of student, and teachers teach according to the actual condition of the students. Thus the teaching is targeted and different from traditional uniform teaching method, the layered teaching method can always set teaching objective which conforms to the students' development, and make teaching and cultivating scheme which conform to the reality of students. In education, although students receive uniform teaching evaluation system, it can develop according to the actual condition of students, which eventually improves the education quality. [6] Education quality has always been the major thinking point of education, and layered teaching method excavates people's potential from the aspect of quality-oriented education, which can be said to grasp the law of education development, and has instructional meaning and value to the future development of the students.

\section{B. Improve Students' Interest in Basketball}

At present, students' interest mainly comes from the outside, namely focusing on competition on TV and gaining form their own games. There are few who gain interest from teaching process, which is mainly because the education faces students, and it's hard to satisfy all the students' studying taste no matter in education mode or education content. The communication between teacher and student is lacked, and students are familiar with their own condition, which will lead students to develop themselves from their own talent but not put the emphasis on teaching class. But the layered teaching method is different, because students can contact with teachers. In education, the objective and guiding scheme is closer to students, thus it will stimulate students' interest and make them gain sense of achievement in targeted education.

\section{Benefit Differentiated Teaching}

Traditional teaching is integral and regards students as a whole. The integration has common features, but in layered teaching method there is difference between students, which means students are not treated as a whole by the teacher. Teachers need to take various teaching measures to satisfy diversified students. In differentiated teaching, students' personality is valued and it will make the best use of the circumstances in teaching design, enabling students to improve practice based on their own advantage. [7] The different physical characteristics of students bring them different teaching schemes. Thus layering will adopt different teaching schemes, but substantially it leads students to the final teaching target but only grasps students' features.

\section{The APPlying STRATEGY OF LAYERED TEACHING METHOD IN BASKETBALL TEACHING IN UNIVERSITIES}

The layered teaching method starts from realistic aspect and thinks about problems based on students, breaks through the former teaching normal form, and focuses on the individual factor of students. The layered teaching method breaks through traditional teaching mode, but we can not always think that there is no advantage of traditional teaching, and the layered teaching method will certainly get expected effect after application. In fact, the layered teaching method disperses teachers' energy, who executes professional education while bearing more pressure, and students may distort education according to their own characters in decomposition of teaching objective.

\section{A. Improve the Identification of the Layered Teaching Method among Teachers and Students}

The application of the layered teaching method is not actually very common in universities currently, and it can be found when considering according to the conditions of universities that there the layered teaching method can not always be effectively executed in teaching. Firstly it is the difficulty of teachers, the layered teaching method means that 
teachers shall put more effort to understand every student and formulate relevant cultivating scheme according to their actual conditions. As far as professional basketball teaching is concerned, it may exist but it is a great challenge for nonprofessional basketball teaching. As far as class hour is concerned, teachers have to time to complete teaching objective. [8] Students mostly hope to practice in free space in sport exercise, however, in layered teaching, there is an oneto-one relationship between teacher and student, and students shall bear the objective pressure from teachers' teaching alone, thus they may take part in teaching unwillingly. To realize the application of the layered teaching method, it needs to firstly eliminate teachers' and students' resistance to layered teaching method, and blend in a brand new concept to change thinking model and pour in more mobilization awareness.

\section{B. Set Differentiated Standard of the Layered Teaching Method}

The layered teaching method divides students into several individuals or groups and then executes targeted education. It needs standard in layered teaching, which is aimed at the layer. When it combines with the basketball teaching in university sports, it needs to consider the feature of basketball. In basketball teaching, students with different constitution may adapt to different sport projects. Basketball is a collective project, which needs the collectivity to coordinate to win. The characters of students are different in layered teaching, and there must be a standard for how to match the feature of students with the feature of basketball, which is confirmed according to constitution of students. According to the stipulation of the layered teaching method, it can execute practice of a certain sport according to constitution of students. There must be certain standard for students in dispersed practice, and difference in objective.

\section{Optimize Relevant Evaluation System of the Layered Teaching Method}

The application of the layered teaching method is good in overall expectation, but it needs a set of evaluation system to normalize the layered teaching, and make it exert its due value. Seeing from the teaching subject of the layered teaching, the teacher is the key, thus during the process of applying the layered teaching, it shall have strict standard to teachers first, and show the factors of the layered teaching from the training of teachers and performance evaluation. Set up evaluation system of the layered teaching method to mobilize students' enthusiasm, find the problems of the layered teaching from the feedback of teaching effect of students, research what needs to further optimize in teaching. Evaluation system is an external supervising system, whose objective is to guarantee improvement of education system. It needs to subdivide the layered teaching mission for establishment of evaluation to guarantee scientization and rationalization of evaluation.

\section{CONCLUSION}

The layered teaching method focuses on students and takes them as the main starting point in education, combines the features of education subjects and seeks for balance between them. Of course, there is still unmatched factor in the application of the layered teaching method, namely when the whole teaching environment is not changed, the layered teaching method has its own advantage, but the loss of expected value in practice can easily cause the misunderstanding of the method, which leads to the deviation from the method application. It needs teachers to distinguish the features of the teaching object to apply layered teaching method to basketball teaching in universities, and integrate teaching resource in judgment and analysis of teaching experience and execute layered teaching method.

\section{References}

[1] Zhang Quanzhong. The application of layered teaching method in basketball teaching in universities [J]. Academy. 2015(30): 15-16.

[2] Zeng Qizhi. Discussion on the application of layered teaching method in basketball teaching in universities [J]. Modern sport technique. 2014(25): $43-44$.

[3] Xiao Kaijun, Liu Zhongqiang. Brief analysis on current condition and method of teaching and training of basketball in universities $[\mathrm{J}]$. Sports. 2014(18): 27-28.

[4] Wang Runsheng, Yang Yang, Liu Kangying. Research on reform and development of basketball teaching in universities [J]. Intelligence. 2014(05): 23-24.

[5] Yang Bo. Exploration and analysis on current condition and reform of basketball teaching in universities $[\mathrm{J}]$. Appliance of recreation and sports and technology. 2014(10): 94-95.

[6] Huo Yongzhou. Discussion on basketball teaching in universities in new age [J]. Modern sports technology. 2013(22):36-37.

[7] Tong Wuyun. The application of layered teaching method in basketball teaching in universities $[\mathrm{J}]$. Talent resource development. 2014(24):47-48

[8] Jiao Zhengwei, Zhu Hanxiao. The application of layered teaching method in basketball teaching in higher vocational education [J]. Management and technology of middle and small-sized enterprises (latter periodical). 2010(11): 55-56. 